\title{
Pre-Service Visual Arts Teachers' Perceptions of Their Experiences of School Practice: A Case of National Teachers College in Uganda
}

\author{
Ssegantebuka Julius
}

\author{
Department of Humanities and Language Education \\ Makerere University, 7062 Kampala, Uganda
}

Doi: 10.2478/ajis-2018-0004

\begin{abstract}
The aim of this study was to describe and analyse the second year pre-service visual arts teachers' perceptions of their experiences of school practice. School practice is a fundamental facet of all teacher preparation that strengthens one's teaching competencies. Pre-service visual arts teachers in National Teacher Colleges (NTCS) in Uganda are trained as generalist on a two-year diploma program, leading to an award of a diploma in secondary education (DSE). During the entire training pre-service visual arts teachers are exposed to twelve weeks of school practice of which six weeks are done in year one and the remaining six weeks of school practice are done in their final second year. The study followed a quantitative research design where a self constructed questionnaire was administered to fifty pre-service visual arts teachers in one of the NTCs. Descriptive statistics were used to analyse the data collected through the questionnaires. Although the research revealed that pre-service visual arts teachers were satisfied with the general prior preparations for the actual teaching, they needed urgent support in using of a number of assessment strategies; accessing and using tools; selecting and using the most appropriate teaching methods and creating an effective learning environment. It was recommended that NTCs expose pre-service visual arts teachers to the ideal school environment that equips them with the necessary knowledge and skills needed for effective teaching and adaptive skills for any teaching context while still at teacher colleges.
\end{abstract}

Keywords: Visual Arts education, School practice, teaching practices

\section{Introduction}

Teaching practice or School practice (as it is commonly known in Uganda) is an important component of teacher training (Heeralal and Bayaga, 2011; Kiggundu and Nayimuli, 2009; Mannathoko, 2013). It exposes the pre-service teachers to the realities of the teaching profession. School practice exposes pre-service teachers to real school situations which require them to practically manage and evaluate class work, maintain discipline and order in classrooms, apply appropriate teaching methods and gain skills in school organisation and administration (Mannathoko, 2013; Mtika, 2008). Through school practice pre-service teachers gain competence in a number of issues such as integrating theory and practice, and work collaboratively with and learn from teachers to prepare a competent, effective and efficient teacher; and to promote ongoing professional development and induction into the teaching profession (Mtika, 2008).

There is considerable number of researches on the role school practice plays in developing trainees theoretical and practical teaching skills, school practice and mentorship, evaluation, duration and how school practice is conducted. However, there are few report research results on these issues in a highly practical-based subject like visual arts. This study therefore is designed to investigate pre-service visual arts teachers' perception of their experiences of school practice in 
developing the theoretical and practical teaching skills in a highly practical-based subject (or in visual arts education).

It is hoped that the results of this study will provide searchlight into college policies governing school practice preparation processes for visual arts. As well, the results might add new insight into how teacher education policy makers, teachers college tutors, school practice evaluators and school practice academic supervisors could better support pre-service visual arts teachers teaching practical-based subjects given their peculiarities. The results might further start a discourse on how to conduct, and assess practical-based subjects like visual arts on school practice.

\subsection{Background to the study}

Uganda currently has five government's aided national teachers colleges (NTCs) of which three are permitted to teach visual arts. These national teacher colleges provide training leading to an award of a diploma secondary education (DSE), which is the minimum required qualification for teaching in secondary schools of Uganda. The NTCs use a visual arts curriculum, prepared by Kyambogo University which has the mandate for DSE training. Pre-service teachers are admitted to NTCs after completing a Uganda advanced certificate of education (UACE). It is a two year program and the pre-service visual arts teachers graduate with a DSE.

\subsection{Visual arts curriculum in NTC}

The visual arts curriculum in national teacher colleges is made up of eleven learning areas which are grouped in three categories. The first category is a two-dimensional art works, composed of graphic design and studio technology, painting and studio technology, textile decoration and studio technology, and drawing (nature, still-life and human figure) and studio technology. The second category is the three-dimensional art works, composed of sculpture and studio technology, pottery and studio technology, multimedia and studio technology and interior decorations and studio technology. The third category is known as the theory category. It is made up of history of art and art appreciation, marketing and principles and methods of teaching art. The visual arts curriculum runs for only two years. Though it is centrally designed based on semester system, it is implemented on term system in the NTCs in Uganda, which encourages omission of some of the visual arts content. The VAC objectives are thin and do not sufficiently address content, teaching and assessment issues. Apart from the visual arts content listed above, this article focuses on the principles and methods of teaching art. This learning area is specific to art and exposes learners to lesson planning and presentation, designing teaching and learning aids, knowledge about child growth and development and preparation for school practice.

\subsection{Conduct of school practice in Uganda}

Pre-service visual arts teachers join NTCs to train as art teachers after successfully completing their Uganda Advanced Certificate of Education (UACE). The school practice in NTCs for second year DSE pre-service visual arts teachers is scheduled in the third term from June to July. Uganda is divided into zones which are headed by zone leaders. During the second term of year two, Preservice visual arts teachers are given introductory letters which they present to schools of their choices where they would like to have their school practice from. When selecting schools for school practice, pre-service visual arts teachers consider at least three main and common issues; (1) schools that will accommodate them; (2) schools that will accept them or (3) schools that are in vicinity with their homes. When a pre-service visual arts teacher is accepted in a given school, the student teacher receives an acceptance letter which he takes to the zone leader in charge of that very zone in which a trainee has found a school. The zone leader compiles a list of pre-service visual arts teachers who are accepted in his zone and forwards it to the school practice coordinator. Then school practice coordinator randomly distributes academic supervisors to zones and schools based on the number of pre-service visual arts teachers in that given zone. During school practice, pre-service visual arts teachers are allocated classes and periods by the director of studies together 
with the subject teacher, but are strictly supervised by their own academic supervisors (not necessarily their subject tutors) from their very colleges. Academic supervisors give pre-service visual arts teachers both written and oral feedback, highlighting strong areas as well as weak areas that need urgent attention. For example; how to apply a variety of teaching strategies, using nonverbal language, explaining explicitly, how to introduce a lesson as well as reviewing it and so forth. The academic supervisor is obliged to observe a pre-service visual arts teacher teaching for at least four lessons. Normally, the academic supervisor does this in the absence of the subject teacher(s), because they always take unofficial leave whenever school practice starts. This research focused on pre-service visual arts teachers' experiences of their school practice, and how it leads to improving their competence levels in teaching. Therefore the study seeks to answer the following research questions:

\subsection{Research questions}

a) What are the pre-service visual arts teachers' views about their general prior preparations to teach specific art disciplines?

b) To what extent does the school experience influence the pre-service visual arts teachers' teaching competencies during the school practice?

c) To what extent does the school practice equip the pre-service visual arts teachers with the knowledge to use a variety of teaching and learning resources?

d) To what extent does the school practice equip the pre-service visual arts teachers with the knowledge to use a variety of teaching methods?

e) To what extent does the school practice equip the pre-service visual arts teachers with the knowledge to use a variety of assessment strategies?

f) How would the pre-service visual arts teachers' rate their teaching competencies generally after the school practice?

\section{Review of Related Literature}

The centrality of school practice in teacher education goes beyond mere exposing pre-service teachers to classrooms; and instead it introduces student teachers to the actual teaching and learning environment (Kiggundu and Nayimuli, 2009; Ngidi and Sibaya, 2003). During school practice, student teachers meet and interact with learners of different age levels and abilities. According to Kasanda, (1995), student teachers get the opportunity to tryout the art of teaching before getting into the real world of the teaching profession. In this case, pre-service teachers learn to plan, prepare and present their lesson plans/knowledge to the learners in the actual school setting.

School practice period can be looked at as a transition period from student hood to a professional teacher (Musingafi, and Mafumbate, 2014). Thus it can be stated that student teachers literally develop into responsible young adults and show the in-charge of peers' learning. They develop knowledge of their subject, since this is the period they affirm or dispute the knowledge some of which learned at college or university (Perry, 2004). School practice offers an opportunity to student teachers to customize own management skills that help them maintain discipline and order in the classroom; become acquitted with school organisation and administration when they are assigned responsibilities as sports masters, matrons or games masters; and school practice exposes student teachers to a variety of teaching approaches; strategies and skills from which they develop own teaching styles and personality (Musingafi, and Mafumbate, 2014).

Student teachers develop knowledge of teacher resources such as lesson planning, teaching skills and assessment strategies as they practically design and implement them. Quoting Mtetwa and Dyanda (2003), Mannathoko, (2013) emphasised that teaching practice offers student teachers with the opportunity to learn and develop as professional teachers along the dimensions of pedagogic knowledge, subject matter knowledge, pastoral knowledge, ecological knowledge, inquiry knowledge and personal knowledge.

School practice provides opportunities for student teachers to integrate theory and practice 
while working closely with experienced teachers (Fraser et al. 2005). In the ideal school environment, student teachers are likely to learn from experienced teachers during interaction. Student teachers also learn from their academic supervisors during conferencing before and after lesson observation. School practice is a challenging experience to student teachers if they are not well prepared in content and handling teacher resources. These challenges may affect student teachers' attitudes towards teaching, and later affect their perception of the teaching profession if not addressed in time (Quick \& Sieborger, 2005)

\subsection{Theoretical review}

This research of the student teachers' perceptions of their experiences of school practice is anchored in the framework of situated learning theory. Situated learning is an instructional approach said to have been developed by Jean Lave and Etiene Wenger in the early 1990s. The theory looks at learning as a social activity where the learner or apprentice actively participates in the learning experience. This social interaction is between the apprentice and the community of experts (Herrington and Oliver 2000). According to Oregon Technology in Education Council, (OTEC) (2007), learning is as a result of the interaction between people and the connecting prior knowledge with authentic, informal, and often unintended contextual learning. And the more the apprentice actively participates in the community of experts, the more he/she learns from his/her experience thus becoming an expert. In this case, where apprentices learn from the experts who are already part of a particular community, the student-teacher therefore needs support that replicates the actual setting or learning environment (Stein, 1998). Quoting Herrington and Oliver, (2000), Ntsaluba and Chireshe, (2013) emphasised the features of learning environments found to be useful for situated learning as including: The provision of authentic context that reflects the way the knowledge will be used in real life; the provision of authentic activities; and the provision of access to expert performances and the modeling of processes. Therefore, the student teachers' ideal learning in and from school practice, calls for the features of situated learning as identified by Herrington and Oliver, (2000). The features of situated learning were used to guide the designing of the data collection tool used in this research.

\section{Methods}

\subsection{Research design}

The research followed a quantitative, descriptive research design. The principal intention of the research was to investigate the second year pre-service visual arts teachers' perception of their experience of school practice in a practical based subject and how it improves their teaching competence level.

\subsection{Participants}

The second year pre-service teachers, enrolled for visual arts education program offered in one of the NTCs in Uganda, constituted the target population for this research. These pre-service visual arts teachers had just returned from a six week period of school practice done in several secondary schools as chosen by individual trainee. The sample consisted of 50 students $36(72 \%)$ male and $14(28 \%)$ female who completed and returned the questionnaire that were distributed.

\subsection{Data collection}

A self constructed questionnaire was administered to the pre-service visual arts teachers who were in one of the NTCs. The questionnaire was divide into sections on pre-service visual arts teachers' biographical data; their general prior preparations to teach; their school experience; their ability to use teaching and learning resources and their level of confidence to teach. 


\subsection{Data analysis}

Descriptive statistics were used to analyse the data collected through the questionnaires. The data were then presented in table format.

\section{Findings of the Research}

4.1 What are the pre-service visual arts teachers' views about their general prior preparations to teach specific art disciplines?

Pre-service visual arts teachers were asked to rate how they have been prepared in a number of aspects by their tutors before experiencing the actual classroom teaching. The results are shown in table 1:

Table 1: Pre-service visual arts teachers views about their general prior preparation to teach

\begin{tabular}{llcccc}
\hline & How would you rate the general preparations & Satisfactory & Unsatisfactory & Not sure & Total \\
before teaching & $\mathbf{4 2}$ & $\mathbf{0 8}$ & $\mathbf{0 0}$ & 50 \\
\hline 1. General prior preparations for teaching & $\mathbf{3 8}$ & $\mathbf{0 9}$ & $\mathbf{0 3}$ & 50 \\
2. School practice briefing & $\mathbf{0 9}$ & $\mathbf{4 1}$ & $\mathbf{0 0}$ & 50 \\
3. Availability of school practice materials & $\mathbf{4 0}$ & $\mathbf{0 7}$ & $\mathbf{0 3}$ & 50 \\
4. Knowledge of the content of the teaching subject & $\mathbf{3 7}$ & $\mathbf{0 7}$ & $\mathbf{0 6}$ & 50 \\
5. Knowledge of teaching skills & & &
\end{tabular}

Majority of the pre-service visual arts teachers $42(84 \%)$ were satisfied with the general prior preparations before teaching. In the same way, $38(76 \%)$ were satisfied with the school practice briefing held at colleges. A total of $40(80 \%)$ of pre-service visual arts teachers expressed their satisfaction with the knowledge of content of the teaching subject, while $37(74 \%)$ were satisfied with the knowledge of teaching skills. About the availability of the school practice materials, 09 $(18 \%)$ were satisfied with the provisional of the school practice materials. However, the biggest number of pre-service visual arts teachers $41(82 \%)$ were dissatisfied with the provisional of the school practice materials. Apart from the provisional of the school practice materials, the remaining four findings out of the five aspects of general preparations before teaching indicated a high level of satisfaction. This means that majority of the pre-service visual arts teachers felt that they had adequate general preparations before actual practice.

4.2 To what extent does the school experience influence the pre-service visual arts teachers' teaching competencies during the school practice?

This question aimed at finding out pre-service visual arts teachers' experiences during their stay in the schools were they had their school practice. The results are shown in table 2:

Table 2: Pre-service visual arts teachers' school experience

\begin{tabular}{llcc}
\hline Student teachers' experiences during school practice & Yes & No & Total \\
\hline 1. I was given the visual arts teaching syllabus at school & 23 & 27 & 50 \\
2. I was comfortable with the classes allocated to me & 33 & 17 & 50 \\
3. The teaching and learning art materials were available & 35 & 15 & 50 \\
4. I was given large classes for art teaching & 19 & 31 & 50 \\
5. My teaching load was fair & 37 & 13 & 50 \\
6. I had regular interaction with the subject teacher(s) & 31 & 19 & 50 \\
7. I was assigned other responsibilities on top of teaching & 39 & 11 & 50 \\
8. I learnt a lot more through hands-on at this school & 41 & 09 & 50 \\
9. I had a separate place/art room for teaching and learning art & 16 & 34 & 50 \\
\hline
\end{tabular}


The results in table 2, indicate the category of school experience, $41(82 \%)$ pre-service visual arts teachers reported having learnt a lot more through hands- on at the host schools; $39(78 \%)$ were assigned other responsibilities on top of teaching; yet $37(74 \%)$ pre-service visual arts teachers agreed that they were given fair teaching loads. Besides, $33(66 \%)$ pre-service visual arts teachers were comfortable with the classes allocated to them, the same with $35(70 \%)$ pre-service visual arts teachers had access to teaching and learning art materials; while 31 (62\%) pre-service visual arts teachers report having interaction with subject teachers on a regular basis. However, a large number of pre-service visual arts teachers $34(68 \%)$ indicated that they had no special rooms for use in teaching art; 31 (62\%) were given large classes for teaching art; 27 (54\%) they did not receive visual arts teaching syllabus for use in teaching; $19(38 \%)$ were not able to interact with subject teachers. yet these are issues for concern in the teaching and learning of visual arts during teaching practice. Generally, the findings indicated that pre-service visual arts teachers had positive perception of their school experience during school practice.

4.3 To what extent does the school practice equips the pre-service visual arts teachers with the knowledge to use a variety of teaching and learning resources?

This question sought to find out the pre-service visual arts teachers frequency of preparation and use of teaching and learning resources. The results are shown in table 3.

Table 3: Teaching and learning resources

\begin{tabular}{|c|c|c|c|c|c|c|}
\hline & $\begin{array}{l}\text { Student teachers' frequency of preparation and use } \\
\text { of teaching and learning materials and tools }\end{array}$ & $\begin{array}{l}\text { Every } \\
\text { lesson }\end{array}$ & $\begin{array}{l}\text { A few } \\
\text { lesson }\end{array}$ & Rarely & $\begin{array}{l}\text { Not at } \\
\text { all }\end{array}$ & Total \\
\hline 1. & Lesson plans & 49 & 01 & 00 & 00 & 50 \\
\hline 2. & Schemes of work & 46 & 04 & 00 & 00 & 50 \\
\hline 3. & Record of work done & 45 & 01 & 04 & 00 & 50 \\
\hline & Designing teaching aids & 28 & 12 & 08 & 02 & 50 \\
\hline 5. & Using physical objects & 25 & 15 & 10 & 00 & 50 \\
\hline & Art materials, tools and equipment & 30 & 11 & 09 & 00 & 50 \\
\hline & Audio-visual resources & 03 & 05 & 05 & 37 & 50 \\
\hline & Computer(s) & 01 & 02 & 00 & 47 & 50 \\
\hline & Overhead projector(s) & 00 & 04 & 00 & 46 & 50 \\
\hline 10. & Art textbooks & 29 & 06 & 10 & 05 & 50 \\
\hline
\end{tabular}

Majority $49(98 \%)$ pre-service visual arts teachers reported that they prepared lesson plans for every lesson; 46 (92\%) prepared schemes of work for every lesson; $45(90 \%)$ were recording every work done or topic covered. Although $30(60 \%)$ pre-service visual arts teachers indicated that they had art materials for every lesson, accessing appropriate tools and equipment was a big problem to them. Besides, only 29 (58\%) pre-service visual arts teachers used art textbooks; 28 (56\%) could design teaching aids and $25(50 \%)$ used physical objects for every lesson. Of greater concern was the use of computers, overhead projector and audio-visual resources, where majority $47(94 \%)$ of pre-service visual arts teachers did not use computers in teaching; 46 (92\%) did not use overhead projectors and $37(74 \%)$ had no access to audio-visual resources respectively. The findings suggest that while the majority of the pre-service visual arts teachers reported having had lesson plans, schemes of work, record of work and art materials for every lesson, accessing and using tools and equipment such as computers, overhead projectors and audio-visual resources was still a big challenge.

\subsection{To what extent does the school practice equips the pre-service visual arts teachers with the} knowledge to use a variety of teaching methods?

The following question sought to establish if the pre-service visual arts teachers were able to use a variety of teaching methods during their school practice. The results are shown in table 4. 
Table 4: pre-service visual arts teachers' use of teaching methods

\begin{tabular}{llcccc}
\hline $\begin{array}{l}\text { Student teachers' use of a variety of } \\
\text { teaching methods during school practice }\end{array}$ & $\begin{array}{c}\text { Every } \\
\text { lesson }\end{array}$ & $\begin{array}{c}\text { Some } \\
\text { lessons }\end{array}$ & Rarely & $\begin{array}{c}\text { Not used at } \\
\text { all }\end{array}$ & \begin{tabular}{c} 
Total \\
\hline 1. Demonstration
\end{tabular} \\
2. Lecturing & $\mathbf{4 4}$ & $\mathbf{1 7}$ & $\mathbf{0 1}$ & $\mathbf{0 2}$ & 50 \\
3. Projects & $\mathbf{1 1}$ & $\mathbf{1 0}$ & $\mathbf{0 8}$ & $\mathbf{1 5}$ & 50 \\
4. Teacher/student discussion & $\mathbf{1 0}$ & $\mathbf{1 2}$ & $\mathbf{1 7}$ & 50 \\
5. Research & $\mathbf{3 5}$ & $\mathbf{1 5}$ & $\mathbf{0 0}$ & $\mathbf{0 0}$ & 50 \\
6. Talk and chalk & $\mathbf{0 5}$ & $\mathbf{0 9}$ & $\mathbf{0 8}$ & $\mathbf{2 8}$ & 50 \\
7. Question and answers & $\mathbf{3 8}$ & $\mathbf{0 7}$ & $\mathbf{0 4}$ & $\mathbf{0 1}$ & 50 \\
8. Group/work/discussion & $\mathbf{3 3}$ & $\mathbf{0 8}$ & $\mathbf{0 5}$ & $\mathbf{0 4}$ & 50 \\
\hline
\end{tabular}

Majority $44(88 \%)$ of the pre-service visual arts teachers reported having used demonstration as a teaching method in every lesson; 38 (76\%) used talk and chalk; $35(70 \%)$ employed teacher/students' discussion; $33(66 \%)$ pre-service visual arts teachers indicated having used question and answers. Beside, $23(46 \%)$ used group discussion and $17(34 \%)$ used lecturing as a teaching method. The least used teaching method was research at $5(10 \%)$ and not used at all by $28(56 \%)$ of the pre-service visual arts teachers in the sample. The findings suggest that while majority of the pre-service visual arts teachers indicated that they used a variety of teaching methods a number of them needed more training in the best way of selecting the most appropriate teaching method best on the content.

4.5 To what extent does the school practice equip the pre-service visual arts teachers with the knowledge to use a variety of assessment strategies?

The following question sought to establish if the pre-service visual arts teachers had the knowledge to use a number of assessment strategies during their school practice. The results are shown in table 5:

Table 5: Pre-service visual arts teachers' use of assessment strategies

\begin{tabular}{llccccc}
\hline $\begin{array}{l}\text { Student teachers' use of a variety of } \\
\text { assessment strategies during school practice }\end{array}$ & $\begin{array}{c}\text { In all } \\
\text { lessons }\end{array}$ & $\begin{array}{c}\text { In some } \\
\text { lessons }\end{array}$ & $\begin{array}{c}\text { Rarely } \\
\text { used }\end{array}$ & $\begin{array}{c}\text { Not used } \\
\text { at all }\end{array}$ & Total \\
\hline 1. Exhibition & $\mathbf{2 7}$ & $\mathbf{2 0}$ & $\mathbf{0 3}$ & $\mathbf{0 0}$ & 50 \\
2. Critiques & $\mathbf{1 6}$ & $\mathbf{1 4}$ & $\mathbf{1 0}$ & $\mathbf{1 0}$ & 50 \\
3. Practical tests & $\mathbf{2 8}$ & $\mathbf{1 5}$ & $\mathbf{0 5}$ & $\mathbf{0 2}$ & 50 \\
4. Presentations & $\mathbf{0 6}$ & $\mathbf{0 7}$ & $\mathbf{1 0}$ & $\mathbf{2 7}$ & 50 \\
5. Portfolio & $\mathbf{0 3}$ & $\mathbf{1 0}$ & $\mathbf{0 5}$ & $\mathbf{3 2}$ & 50 \\
6. Essays & $\mathbf{0 9}$ & $\mathbf{1 1}$ & $\mathbf{0 7}$ & $\mathbf{2 3}$ & 50 \\
7. Multiple choice questions & $\mathbf{0 5}$ & $\mathbf{1 3}$ & $\mathbf{1 1}$ & $\mathbf{2 1}$ & 50 \\
\hline
\end{tabular}

In table 5, 28 (56\%) pre-service visual arts teachers used practical tests; 27 (54\%) used exhibition as an assessment style; $16(32 \%)$ pre-service visual arts teachers reported having used critiques as assessment style in all lessons. Of concern is the use of portfolio, presentations, essays and multiple choice questions. The $32(64 \%)$ of pre-service visual arts teachers did not use portfolio at all; 27 (54\%) did not use presentations at all; 23 (46\%) pre-service visual arts teachers did not use essays at all; and the $21(42 \%)$ did not use multiple choice questions are all these are causes for concern. The findings indicated that majority of the pre-service visual arts teachers are struggling with the choice and use of a number of assessment strategies.

\subsection{How would the pre-service visual arts teachers' rate their teaching competencies generally after the school practice?}

The following question sought to establish the pre-service visual arts teachers' teaching competence levels generally after the school practice. As indicated in the table 6 . 
Table 6: General teaching competence levels

\begin{tabular}{llccc}
\hline & Student teachers rate their competence levels after & Satisfactory & Unsatisfactory & Total \\
\hline school practice & $\mathbf{3 1}$ & $\mathbf{1 9}$ & 50 \\
\hline 1. Using teaching aids effectively & $\mathbf{4 4}$ & $\mathbf{0 6}$ & 50 \\
2. I can prepare and effectively present an art lessons & $\mathbf{3 6}$ & $\mathbf{1 4}$ & 50 \\
3. Preparing effective teaching materials for visual arts & $\mathbf{3 2}$ & $\mathbf{1 8}$ & 50 \\
4. Employing a number of effective teaching methods & $\mathbf{2 4}$ & $\mathbf{2 6}$ & 50 \\
5. Creating an effective learning environment for visual arts & $\mathbf{1 6}$ & $\mathbf{3 4}$ & 50 \\
6. I have the ability to design an effective assessment tool & $\mathbf{1 4}$ & $\mathbf{3 6}$ & 50 \\
7. Using formative and summative assessment & $\mathbf{4 3}$ & $\mathbf{0 7}$ & 50 \\
8. Improved content knowledge for visual arts & $\mathbf{3 9}$ & $\mathbf{1 1}$ & 50 \\
9. Ability to manage students of different background & &
\end{tabular}

Majority $44(88 \%)$ of the pre-service visual arts teachers reported having acquired the ability to effectively prepare and present an art lessons; 43 (86\%) had improved knowledge; 39 (78\%) have the ability to manage students of different background; $36(72 \%)$ could prepare effective teaching materials for visual arts; $32(64 \%)$ developed the ability to employ a number of effective teaching methods; and only $31(62 \%)$ developed the ability to use teaching aids effectively. Of concern were the $36(72 \%)$ pre-service visual arts teachers who were unsatisfied with formative and summative assessment; 34 (68\%) were dissatisfied with designing an effective assessment tool; 18 (36\%) did not develop the ability to create an effective learning environment; $19(38 \%)$ were dissatisfied with using teaching aids; and $18(36 \%)$ did not develop the ability to use a number of teaching methods. The findings suggest that while the majority of pre-service visual arts teachers reported having developed satisfactory abilities in the five areas out of nine, assessment, creating an effective learning environment, using teaching aids and using a variety of teaching methods are still a problem for a considerable number of pre-service visual arts teachers.

\section{Discussion}

The research aimed at exploring pre-service visual arts teachers' perception of their experiences of school practice. The findings presented indicated that the six weeks supervised school practice exposed more learning areas in which pre-service visual arts teachers were inadequately prepared than those were they are adequately prepared. The learning areas in which pre-service visual arts teachers had limited abilities included; designing an effective assessment tool, creating an effective learning environment, using teaching aids and using a variety of teaching methods. This finding can be attributed to the fact that, pre-service visual arts teacher preparation in Uganda draws distinct differences between content studied in education department from that content studied in the visual arts department. In this case the learning areas where pre-service visual arts teachers showed weaknesses are all studied in the education department. This means that pre-service visual arts teachers were give the opportunity practically integrate and apply the theoretical knowledge as well as newly acquired teaching skills (Kiggundu, 2007; Mtika, 2008).

The results in table 1 , indicated that majority of the pre-service visual arts teachers were satisfied with their general preparation before going to different schools for actual teaching. However, $82 \%$ of the pre-service visual arts teachers were dissatisfied with the provisional of the school practice materials. School practice materials in national teacher colleges include pens, markers, Manila paper sheet and a student's school practice preparation book in which lesson plans, record of work and schemes of work are done. Pre-service visual arts teachers reported that instead they were give only ten ruled sheets and a paper folder file which made their preparation hard. Yet according to Foncha et al (2015), lack of resource materials frustrates pre-service visual arts teachers, making school practice a difficult experience. Based on the finding of the research the provisional of school practice materials need urgent attention.

The findings of this research revealed that majority of the pre-service visual arts teachers had positive perception of their school experience during school practice, as indicated in table 2 . Although majority of the pre-service visual arts teachers had positive perception of their school 
experience, a considerable number of them had challenges. They had no special rooms for use in teaching art, they were given large classes for teaching art, they did not receive visual arts teaching syllabus for use in teaching and were not able to interact with subject teachers. Beside, pre-service visual arts teachers reported having benefitted in a number of aspects such as learning a lot through hands-on at the host school(s) and also having been exposed to other responsibilities within a school on top of teaching. This implies that to a large extent the host school(s) provided pre-service visual arts teachers with the opportunity to integrate theory and practice in an authentic learning environment and to expose them to real demands of the teaching profession (Mtika, 2008).

Regarding pre-service visual arts teachers' frequency of preparation and use of teaching and learning resources, majority reported having prepared lesson plans, schemes of work, recording every topic covered, had art materials, and used art textbooks for every lesson. However, a considerable number of pre-service visual arts teachers reported having had problems in accessing appropriate tools and equipment and also the quantity and quality of art materials accessed was an issue of concern. The research further revealed that computers, overhead projectors and audiovisual resources, were not used at all, as indicated in table 3. Majority of pre-service visual arts teachers reported that in most of the schools they went to, had no computers, overhead projectors and audio-visual resources. Yet in some schools were they were pre-service visual arts teachers who were there, admitted that they lacked knowledge of using them. This was attributed to the lack of exposure to technology during teacher preparation. Yet technology improves on knowledge search and knowledge presentation as stated by (Ssegantebuka, 2016). This finding confirms Schmidt et al (2009) suggestion of the need for tutors to integrate technological knowledge in teaching. Based on the finding of the research therefore, exposing pre-service visual arts teachers to the use of technology in teaching during the teacher preparation calls for urgent attention.

Several researchers show the need for teachers to develop the ability to select and use a variety of teaching methods during teaching (Clark \& Starr, 1986; Eison, 2010). The use of a variety of teaching methods is vital as it is only through teaching methods tutors present the knowledge and skills. Different teaching methods give students different learning opportunities in a learning situation, most especially the active teaching methods (Eison, 2010). However, the study findings revealed that pre-service visual arts teachers need more training in the best way of selecting and using the most appropriate teaching method best on the content.

Although the research findings showed that pre-service visual arts teachers used practical tests, exhibition, and critiques as assessment strategies in all lessons, portfolio, presentations, essays and multiple choice questions were not used at all, as indicated in table 5 . This could be attributed to the assessment strategies regular teachers are using and pre-service visual arts teachers' knowledge of the very assessment strategies as well as what their students are used to in the host schools. This finding confirms Senyondwa's (2013) statement that teachers cannot use assessment strategies they are not familiar to. However, pre-service visual arts teachers reported that they lacked knowledge of using such assessment strategies. This implies that there is a need to expose pre-service visual arts teachers to a number of assessment strategies during their teacher preparation while still at college. The findings further indicated that majority of the preservice visual arts teachers are struggling with the choice and use of a number of assessment strategies including those they claimed to have used during school practice. Based on the finding of the research therefore, exposing pre-service visual arts teachers to a number of assessment strategies in teaching during their college preparation is significant.

Regarding general competence acquired during school practice, pre-service visual arts teachers reported having developed minimal abilities in the use of formative and summative assessment, designing effective assessment tools, ability to create an effective learning environment, designing and using teaching aids and using a number of teaching methods-as indicated in table 6 . The findings suggest that while the majority of pre-service visual arts teachers reported having developed satisfactory abilities in the six areas out of nine, assessment, creating an effective learning environment, using teaching aids and using a variety of teaching methods are still a problem for a considerable number of pre-service visual arts teachers. Yet they are core in effective teaching and learning in visual arts. 


\section{Conclusion}

The findings confirm that school practice prepares the pre-service visual arts teachers for the school dynamics. Much as school practice prepares pre-service visual arts teachers for the real demands of the teaching profession, there are quite a number of challenges that are associated with pre-service teacher preparations. These challenges are more associated with the training institutions than the secondary schools pre-service teachers go to. For example, teachers colleges fail to provide quality as well as adequate school practice materials, which would help pre-service visual arts teachers get adequate preparation before actual teaching. Additionally, teachers colleges do not expose pre-service visual arts teachers to technology that would help them in knowledge search and presentation. The findings indicated that a number of pre-service visual arts teachers were found with limited knowledge of using technology like computers, audio-visual resources during school practice. Pre-service visual arts teachers were found with limited knowledge of using active teaching methods. The findings suggested more training in the best way of selecting the most appropriate teaching methods best on the content. In practical-based subjects pre-service visual arts teachers need to have had exposure to a number of art materials, tools and equipment before the actual teaching for them to develop ability to use them during school practice. The colleges did not also expose pre-service visual arts teachers to a number of assessment strategies that would make their teaching and learning beneficial to them and their learners.

Secondly, there were issues directly concerning the schools were pre-service visual arts teachers had their school practice activities. For example, poorly resourced schools gave preservice visual arts teachers a nasty experience. Since pre-service visual arts teachers are the ones choosing schools to go to, they normally consider; nearness to home, likely to retain me or have accommodation, but not the quality of the school. Poorly resourced schools were seen having no art-rooms to teach from, no art materials and usually have large classes. Non-involvement of regular teachers in school practice was also an issue of concern. In Uganda, regular teachers have a tendency of taking school practice period as a time for leave. They normally go for leave to attend to personal issues, leaving classes to pre-service visual arts teachers without close supervision from the expert teachers.

\section{Recommendations}

There is need for NTCs, host schools and host teachers to work collaboratively during and after school practice activities. This will help NTCs prepare pre-service visual arts teachers to the expectations of the secondary schools. It is recommended that NTCs expose pre-service visual arts teachers to the ideal school environment that equips them with the necessary knowledge and skills needed for effective teaching and adaptive skills for any teaching context while still at teacher colleges. It is recommended that colleges participate in the selection of secondary schools for school practice, so that pre-service visual arts teachers are sent to well resourced schools from which learners will be exposed to a number of resources. It is important for NTCs to involve host schools and host teachers in the planning and conducting of school practice in order to; provide relevant information about the school, secure well planned induction, locate fairly small number of learners to pre-service visual arts teachers and provide opportunities for pre-service visual arts teachers to develop their professional knowledge.

\section{References}

Clark, L. H., \& Starr, I. S. (1986). Secondary and middle school teaching methods. Glencoe/McGraw-Hill School Pub Co.

Eison, J. (2010). Using active learning instructional strategies to create excitement and enhance learning. Retrieved from http://www.cte.cornell.edu/documents/presentations/EisenHandout.pdf

Foncha, J. W., Abongdia, A. A., \& Adu, E. (2015). Challenges encountered by student teachers in teaching english language during teaching practice in East London, South Africa. International Journal of Educational Sciences, 9(2), 127-134. 
Fraser, W. J., Killen, R., \& Nieman, M. M. (2005). Issues in competence and pre-service teacher education. Part 2: the assessment of teaching practice. South African Journal of Higher Education, 19(2), $246-259$. http://hdl.handle.net/10520/EJC37136

Heeralal, P. J., \& Bayaga, A. (2011). Pre-service teachers' experiences of teaching practice: case of South African University. Journal of Social Sciences, 28(2), 99-105.

Herrington, J., \& Oliver, R. (2000). An instructional design framework for authentic learning environments. Educational technology research and development, 48(3), pp. 23-48.

Kasanda, C. D. (1995). Teaching practice at the University of Namibia: Views from student teachers. In E. Kiggundu, \& S. Nayimuli, (Eds.), Teaching practice: a make or break phase for student teachers. South African Journal of Education, 29(3), pp. 345-358.

Kiggundu, E., \& Nayimuli, S. (2009). Teaching practice: a make or break phase for student teachers. South African Journal of Education, 29(3), pp. 345-358.

Kiggundu, E. (2007). Teaching practice in the Greater Vaal triangle area: The student teachers' experience. Journal of College Teaching and Learning, 4(6): pp. 25-36. DOI: http://dx.doi.org/10.19030/tlc.v4i6.1572

Mannathoko, M. C. (2013). Does teaching practice effectively Prepare student-teachers to teach creative and performing arts? The case of Botswana. International Journal of Higher Education, 2(2), pp. $115-121$. DOI: https://doi.org/10.5430/ijhe.v2n2p115

Mtetwa, D. K., \& Dyanda, C. (2003). Outcomes of a teaching practice. Improving teacher preparation: Teaching practice guide. In M. C. Mannathoko. (Eds.), Does teaching practice effectively Prepare student-teachers to teach creative and performing arts? The case of Botswana. International Journal of Higher Education, 2(2), pp. 115-121. DOI: https://doi.org/10.5430/ijhe.v2n2p115

Mtika, P. D. G. (2008). Teaching practice as a component of teacher education in Malawi: An activity theory perspective (doctoral thesis). Nottingham: University of Nottingham.

Musingafi, M.C.C. \& Mafumbate, R. (2014).Challenges and prospects for school based mentoring in the professional development of student teachers in Zimbabwe: Academics, Mentees and Mentors Perceptions. Asian Journal of Economics and Empirical Research, 1(2), pp. 32-39. http://asianonlinejournals.com/index.php/AJEER

Oregon Technology in Education Council, (OTEC) (2007). Situated learning (from: theories and transfer of learning). http://otec.uoregon.edu/learning_theory.html\#Situated Learning

Quick, G., \& Sieborger, R. (2005). What matters in practice teaching? The perceptions of schools and students. In M. C. Mannathoko. (Eds.), Does teaching practice effectively Prepare student-teachers to teach creative and performing arts? The case of Botswana. International Journal of Higher Education, 2(2), pp. 115-121. DOI: https://doi.org/10.5430/ijhe.v2n2p115

Schmidt, D. A., Baran, E., Thompson, A. D., Mishra, P., Koehler, M. J., \& Shin, T. S. (2009). Technological pedagogical content knowledge (TPACK) the development and validation of an assessment instrument for pre-service teachers. Journal of Research on Technology in Education, 42(2), pp. 123-149.

Ssegantebuka, J. (2016). Tutors' knowledge-base and the preparation of pre-service visual arts teachersin Uganda (Unpublished doctoral Thesis). Makerere University, Kampala-Uganda.

Ssenyondwa, P. (2013) Teaching sculpture in national teacher colleges in Uganda (Unpublished master thesis). Kyambogo University, Kampala-Uganda.

Stein, D. (1998). Situated Learning in Adult Education. ERIC Digest No. 195. 